\title{
ГЕОГРАФИЯ
}

\author{
С. Г. Половка
}

Уманський державний педагогічний університет імені Павла Тичини

\section{ІСТОРИЧНІ ВІХИ І-ОЇ МОРСЬКОЇ ЕКСПЕДИЦІЇ ДОСЛІДНИКІВ АН УРСР (НАН УКРАЇНИ) В ТРОПІЧНУ АТЛАНТИКУ ТА ЇЇ ЗНАЧЕННЯ ДЛЯ ПОДАЛЬШОГО РОЗВИТКУ ГЕОЛОГІЇ ОКЕАНІВ І МОРІВ В УКРАЇНІ}

Статтю присвячено І-й для українських дослідників АН УРСР (НАН України) морській експедиції (ХІІ рейс НДС «Михаил Ломоносов») в Тропічну Атлантику та здійснено історичний зріз її значення для подальшого розвитку морської геології в УРСР (Україні).

Ключові слова: морська геологія, ХІІ рейс НДС «Михаил Ломоносов», Тропічна Атлантика, наукові напрями та школи, науково-дослідний флот України.

Статья посвящена І-й для украинских исследователей АН УССР (НАН Украины) морской экспедиции (XII рейс НДС «Михаил Ломоносов») в Тропическую Атлантику и сделан исторический срез ее значения для дальнейшего развития морской геологии в УССР (Украине).

Ключевые слова: морская геология, НИС «Михаил Ломоносов», Тропическая Атлантика, научные направления и школы, научно-исследовательский флот Украины.

The article is devoted to the I-th Ukrainian SSR researchers (NAS) sea expedition (XII flight VAT «Mikhail Lomonosov») in the tropical Atlantic. Briefly describe the development of marine geology at different periods of its existence: in the days of the USSR and Ukraine. Made a historic section of the development of scientific areas and schools, geological dynasties, the development of hardware and methods, improving the methods of research in the sea, providing swimming facilities maritime expeditions (surface and submarine fleet) and displayed in terms of the further development of the geology of the oceans and seas in Ukraine.

Key words: Marine geology, research vessel «Mikhail Lomonosov», Tropical Atlantic, research areas and schools, research fleet in Ukraine.

Вступ. У 1961 р. Морський гідрофізичний інститут (МГІ) АН СРСР було переведено 3 Москви до Севастополя в підпорядкування АН УРСР і його директором призначено А.Г. Колеснікова. Аркадій Георгійович добре розумів необхідність комплексного підходу до вивчення Світового океану. Через Океанографічну комісію при Президії АН УРСР, яку він на той час очолював, за його ініціативи та підтримки обов'язковим елементом будь-якої морської експедиції і вводиться геологія з 1962 р. вчені Інституту геологічних наук (ІГН) АН УРСР отримали змогу збирати фактичний матеріал 3 дна акваторії Світового океану.

Постановка проблеми. Академік В. I. Вернадський, який започаткував історію науки і техніки як окремий науковий напрям, на питання, яке задавалося йому неодноразово: «Для чого потрібна історія науки?», відповідав: «Щоб знайти нове та не робити помилок минулого». Вивчати минуле, пов'язувати його 3 сучасним потрібно ще й для того, щоб чіткіше уявляти шляхи розвитку науки на близьке майбутнє.

(C) С. Г. Половко, 2014 
Аналіз останніх досліджень і публікацій. Історія розвитку морських геологічних досліджень в АН УРСР (НАН України) та ії складові неодноразово висвітлювались у різних 3МІ і їм присвячено низку наукових праць [1-12 та ін.].

Постановка завдання. Нами зроблено спробу в 50-ту річницю 3 дня завершення першої офіційної для українських морських геологів АН УРСР (НАН України) експедиції, яка відбулась під час XII рейсу НДС «Михаил Ломоносов» в Тропічну Атлантику, відтворити історичний перебіг подій, які спонукали до цієї морської експедиції та нагадати науковій спільноті про офіційний початок досліджень дна акваторії Світового океану українськими дослідниками.

Викладення основного матеріалу. Фундаторами морської геології як науки були вчені Новоросійського (нині Одеського) університету М. О. Головкінський, М. І. Андрусов та ін., піонерами морських геологічних досліджень в АН УРСР (НАН України) - акад. АН УРСР А.Г. Колесніков, чл.-кор. АН УРСР А. С. Бабинець та акад. АН УРСР С. Ф. Шнюков.

У період апогею боротьби фіксистів і мобілістів офіційно було започатковано морську геологію в УРСР (Україні) (1962р.). Основним завданням морських геологічних експедицій було накопичення фактичних матеріалів щодо геологічної будови Атлантичного океану з метою аргументації фіксистських чи мобілістичних поглядів на еволюцію земної кори і літосфери.

Морська геологія - відносно новий науковий напрям у складі традиційних геологічних наук, який розпочав розвиватися в кінці XIX ст., особливо інтенсивно в післявоєнні роки і нині сформувався у самостійну галузь фундаментальних досліджень, що має в своєму арсеналі специфічні, властиві тільки методи отримання та інтерпретації геологічних даних. Значення їх полягає як у можливості вирішення глобальних теоретичних питань історичного розвитку Землі в цілому, так і практичних завдань, пов'язаних з освоєнням та раціональним використанням мінеральних та біологічних ресурсів Світового океану.

В останні роки ми є свідками зростаючого інтересу дослідників з різних галузей геологічних наук до вивчення природи тієї частини планети, яку покривають води Світового океану. Цей закономірний інтерес продиктовано, у першу чергу, логікою поширення наукового пізнання кожної з цих наук 3 метою розкриття глобальних закономірностей геодинамічної еволюції Землі.

По-друге, він визначається необхідністю вивчення специфічної будови рельєфу дна і геодинаміки підводних надр 3 метою виявлення закономірностей генерації і локалізації різних видів мінеральних ресурсів на морському дні та в його надрах.

Весною 1962 р. ІГН АН УРСР отримав завдання на проведення геологічних досліджень у Світовому океані. Торкаючись організаційних моментів експедиції, слід зазначити, що на цей час в АН УРСР не було фахівців, які б мали досвід геологічних робіт у морі, та обладнання, яким потрібно здійснювати різні забортні роботи - зондувати дно акваторії Світового океану.

Стосовно першого - тодішній директор ІГН АН УРСР акад. АН УРСР В. Г. Бондарчук (автор теорії тектоорогенії), який ініціював офіційне внесення в план робіт інституту морської тематики. Володимир Гаврилович був науковим керівником кандидатської дисертації В. І. Мельника і добре знав, що його учень Віктор Іванович має військову спеціальність, яка відноситься до Військовоморського флоту. Він йому доручає зайнятися підготовкою експедиційного загону, який буде вивчати морське дно Атлантики. 3 цією метою Володимира Івановича Мельника відряджають у Москву на навчання до засновника радянської школи 
морських геологів проф. Марії Василівни Кльонової. Крім цього, Володимир Іванович додатково пройшов стажування в Інституті океанології АН СРСР.

У підготовчий період до майбутньої експедиції в Києві за рекомендацією «морської левиці», так називали морські геологи РАН СРСР М. В. Кльонову, було підготовлено 4 грунтові прямоточні трубки (d=78 мм, довжиною по $3,5 \mathrm{M})$ та дночерпачі. Це забортне обладнання повинне за допомогою тросу опускатися на дно моря, відбирати пробу грунту та підійматися на палубу. Крім цього, було підготовлено й інше обладнання (експериментальний варіант поршневої грунтової трубки, запасні троси, дночерпачі), яке в Калінінграді було загружене на судно.

4 жовтня 1962 р. $з$ п. Калінінград НДС «Михаил Ломоносов» відправилося в свій XII рейс. На цьому судні був загін морських геологів з ІГН АН УРСР у складі 4 дослідників, а саме: доктора геол.-мін. наук А. С. Бабинця - керівника групи, ст. н. с., канд. геол.-мін. наук Б. Ф. Зернецького, мол. н. с. В. І. Мельника (рис. 1) та ст. інж. С. В. Смірнова. Ці вчені з АН УРСР відправилися в першу офіційну для українських дослідників дна акваторії Світового океану морську експедицію до Тропічної Атлантики.

Метою цієї експедиції був збір фактичного матеріалу з геології Атлантики.

Маршрут експедиції був наступним: Калінінград - Гібралтар, Гібралтар Дакар, Дакар - Реєнфі, Реєнфі - Ріо-де-Жанейро, Ріо-де-Жанейро - Гібралтар, Гібралтар - Неаполь, Неаполь - Севастополь.

Пройшовши Балтику, протоку Ла-Манш, увійшли до Біскайської затоки, води якої зустріли експедиціонерів десятибальним штормом. Ось так відбулося перше «хрещення Нептуна». Сама природа 3 перших кроків українських дослідників до таємниць акваторії дна океанів і морів вирішила випробувати їх на міцність.
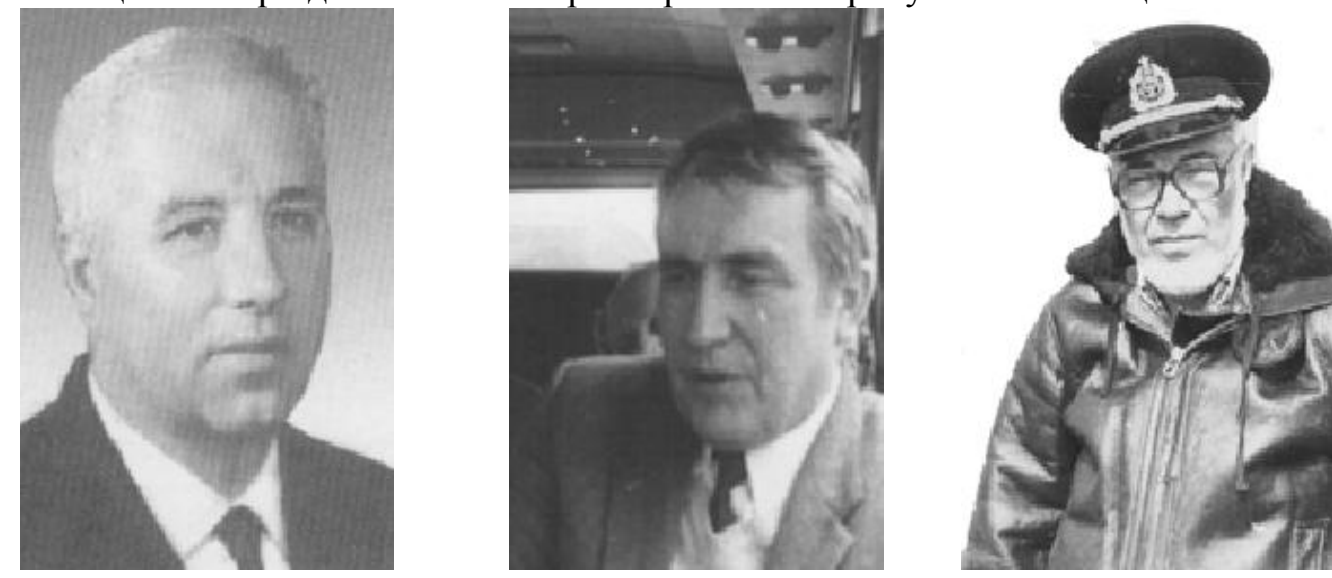

Рис. 1. Учасники ХII рейсу НДС «Михаил Ломоносов» (1962 р.) (зліва направо: А. С. Бабинець, Б. Ф. Зернецький та В. І. Мельник)

Після заходу в Гібралтар, де було поповнено запаси харчів і питної води, НДС «Михаил Ломоносов» вийшло у відкритий океан для виконання програми рейсу.

На двох перших станціях М. В. Кльонова розпочала практичне навчання українських морських геологів брати проби грунту з дна акваторії Світового океану. Хоча теоретично українські дослідники були підготовлені добре, але практичних навичок і тонкощів методики здійснення підняття грунтових трубок не мали. Тим паче, що глибина моря в районі на початку «навчальних робіт» сягала 
4000-5000 м, а відбір донних проб з таких глибин - це велика майстерність, яку не так просто опанувати, i, як результат, було «потоплено» 4 прямоточні грунтові трубки та 15 км тросу.

Втративши ці грунтові трубки, українські вчені були змушені використовувати важку грунтову трубку довжиною 8 м і діаметром 127 мм. Науковці ІГН АН УРСР за допомогою машинної команди НДС «Михаил Ломоносов» намотали на барабан лебідки нову необхідну для роботи кількість тросу та підготувати через добу до спуску нову грунтову трубку. Ось один із прикладів злагодженої роботи команди судна та наукового складу, які спільно направляють свої зусилля і працюють на виконання завдань експедиції, чого бракує у нинішніх експедиційних роботах у морі.

Нагородою такої плідної співпраці між командою судна і науковцями став перший спуск важкої грунтової трубки, який мав неабиякий успіх. Піднявши цю грунтову трубку, дослідники з АН УРСР з'ясували, що грунтова колонка сягала довжини 4,5 м при діаметрі грунтової трубки 127 мм. Це був рекорд, так як на цьому судні 3 такими важкими трубками ніхто до цього не працював. В подальшому також опускали експериментальну поршневу грунтову трубку, яка була об'єднана $з$ двома дночерпачами.

Наголосимо, що робота у відкритому океані йшла цілодобово і досить напружено, станції слідували за станцією. Дослідники АН УРСР під час переходу між станціями, де спускалося різне гідрофізичне, біологічне та інше забортне обладнання, несли восьмигодинні вахти на ехолоті, який працював безперервно на шляху слідування НДС «Михаил Ломоносов».

Під час проведення цієї експедиції українські дослідники поклали початок накопиченню фактичного матеріалу з Тропічної Атлантики, шельфу Західної Африки і Бразилії та інших частин Світового океану. На зворотному шляху слідування судна в акваторії Чорного моря також були здійснені подібні роботи, які доповнили фактичним матеріалом XII рейс НДС «Михаил Ломоносов». Нині цей фактичний матеріал (керн i т. п.) зберігається в керносховищі (с. Велика Салтанівка, Васильківський р-н., Київська обл.), яке зберегли співробітники відділу сучасного морського седиментогенезу ІГН НАН України (зав. відділом доктор геол.-мін. наук, чл.-кор. НАН України, проф. О. Ю. Митропольський).

9 січня 1963 р. НДС «Михаил Ломоносов» кинуло якір у п. Севастополь, що означало завершення його XII рейсу, значення якого для української та світової науки про дно океанів і морів досить важко оцінити і нині.

Допитливий читач може поставити питання: «А що особливого в цій експедиції? Такі та інші експедиції в акваторію Світового океану були і вони були більш вагоміші в науковому та прикладному надбанні». Хотілося б зазначити, говорячи про морські експедиції в цілому, наголосимо, що кожна 3 них виокремлюється своєю індивідуальністю. Основна увага нами приділена першій знаковій експедиції, яка знаменувала якісно новий етап вивчення дна Світового океану та заклала фундамент подальшого розвитку геології океанів і морів в АН УРСР (НАН України).

Якщо коротко охарактеризувати пройдений науковий шлях морських геологічних досліджень за 50 років їх існування в АН УРСР (НАН України), слід наголосити на тому, що 3 часу офіційного заснування морських геологічних досліджень в Україні вивчення дна акваторії Світового океану здійснювалося за традиційними науковими напрямами, які розвиваються i нині: 1) морські біостратиграфічні дослідження - В.Я. Дідковський, В.М. Семененко, Б. Ф. 
Зернецький, М. М. Іванік та ін.; 2) морські седиментологічні та літологічні дослідження - В. Х. Геворкян, В. І. Мельник, О. Ю. Митропольський, В. П. Усенко та ін.; 3) морська геоморфологія - П. Ф. Гожик, В. І. Мельник та ін.

Подальші теоретичні та прикладні напрацювання українських дослідників дна акваторії Світового океану визначили коло інтересів та завдань у конкретних акваторіях для досліджень і створили підгрунтя для започаткування в АН УРСР (НАН України) нових наукових напрямів, які і нині мають місце та продовжують свій розвиток: 1) морська гідрогеологія та морська інженерна геологія А. Є. Бабинець, О. Ю. Митропольський, Г. О. Білявський та ін.; 2) морське осадове рудоутворення - С. Ф. Шнюков та ін.; 3) глибинні флюїди та їх роль у формуванні родовищ корисних копалин та біопродуктивних зон (В.Х. Геворкян, Ю. Г. Чугунний); 4) підводні морські геологічні дослідження - В. Х. Геворкян; 5) морська геохімія - О. Ю. Митропольський, А. А. Дроздовська та ін.; 6) морська геоекологія - Є.Ф. Шнюков, В. О. Смельянов, О. Ю. Митропольський, В. Х. Геворкян та ін. [5; 11].

Якщо торкнутися питання наукових шкіл у галузі океанів і морів, то визнаними лідерами або засновниками $є$ академік АН УРСР В. Г. Бондарчук та академік НАН України Є.Ф. Шнюков. Відгалужуються наукові напрями, які очолюють А. Є. Бабинець, В. Я. Дідковський, П. Ф. Гожик, В. Х. Геворкян, О. Ю. Митропольський, І. П. Зелінський, Є. П. Ларченков та ін.

Нині сформувався потужний загін науковців, який спроможний подолати кризу і вивести морську геологію на чільне місце серед країн 3 розвиненим морегосподарським комплексом. I підтвердження цьому - не тільки ті морські геологи, які прийшли в морську геологію з геологічних родин (Р. Я. Бєлєвцев, В. М. Семененко, I. М. Скопіченко, I. М. Байсарович, С. Ю. Лебедєв, О. В. Скаржинський, Г. М. Ладиженський, Є. І. Насєдкін), а й щойно народжувані династії - Є. Ф. Шнюков, С. С. Шнюков, К. Є. Шнюкова; Р. Х. Греку, Т. Р. Греку; В. І. Мельник, О. В. Мельник; В. М. Кадурін, С. В. Кадурін; О. П. Кравчук, Г. О. Кравчук; С. О. Клещенко, Т. С. Куковська; М. М. Іванік, Н. В. Маслун, О. М. Іванік; В. П. Вернигоров, Д. В. Вернигоров, Ю. В. Вернигорова [11] та нині діючі геологічні школи та існуючі наукові напрями в цій галузі науки.

Українські дослідники для пізнання акваторії Світового океану використовували загальноприйняті методи і методики, що були на озброєнні в океанології СРСР, але поряд з цим, вони розробили методичні та апаратурні засади ядерно-фізичних методів геологічних досліджень осадів акваторії (апаратура i методи визначення водно-фізичних властивостей донних відкладів та вивчення гідрохімії порових вод) та створили й удосконалили методики, а саме: 1. методику дослідження в спеціалізованих геологічних експедиціях на гідрографічних i океанологічних судах; 2. методику експрес-аналітичних досліджень хімічного складу та фізико-механічних властивостей морських осадів в спеціалізованих геологічних експедиціях; 3. методику застосування різно типових підводних апаратів для геологічних і екологічних досліджень акваторії Світового океану [11].

Відповідно до останніх новітніх розробок українських дослідників дна Світового океану, слід акцентувати увагу на тому, що у відділі геоекології та пошукових досліджень ІГН НАН України (зав. відділом І. Б. Багрій) розроблено та впроваджено комплекс апаратури нового покоління для проведення атмогеохімічних, термометричних та еманаційних досліджень 3 метою 
забезпечення надійного прогнозу вибору ділянок під пошукове буріння на нафту і газ [11].

УРСР (Україна), яка свого часу мала потужний морегосподарський комплекс і технічне забезпечення, наукові та геополітичні інтереси держави поширюються на акваторію Світового океану в цілому. Україна як член ООН активно співпрацює 3 ЮНЕСКО в морських галузях. За історію свого існування геологія океанів і морів свого розквіту зазнала в УРСР. Нинішній етап складний, неоднозначний і має різну оцінку вчених. Деякі 3 них оцінюють його як стагнацію морських експедиційних робіт та занепад теоретичних досліджень. Інші розвивають ідеї про переосмислення стратегічних підходів до розвитку цієї галузі науки в нашій державі, узагальнення наукових теоретичних і практичних розробок, налагодження наукових контактів 3 міжнародною спільнотою і т. п.

У нинішніх умовах розвитку геології океанів і морів в Україні, на наше переконання, потрібно виробити єдину думку про майбутнє даної галузі науки, якій у нашій державі альтернативи немає. Без відродження морської геології ми не вбачаємо великої перспективи для економічного розвитку держави Україна, яка повинна не декларувати свій морський статус, а бути повноцінною морською державою з належним повноцінним морегосподарським комплексом.

Стисло підсумовуючи загальне значення наукових напрацювань дослідників iз різних країн світу в галузі геології океанів і морів, слід наголосити на тому, що без морської геології не може бути геології зовсім. Всі гіпотези, всі нові дані про Землю було перевірено завдяки морській геології, і українська частка в цих напрацюваннях є значною.

Висновки. На основі наших досліджень слід зробити наступні висновки.

1. XII рейс НДС «Михаил Ломоносов» офіційно поклав початок морським експедиційним дослідженням українських вчених в акваторії Світового океану та відродив започатковану вченими Новоросійського університету новітню галузь науки - геологію океанів і морів.

2. Здобутий у морі фактичний матеріал допоміг накреслити подальший план досліджень акваторії Атлантичного океану та інших його частин.

3. Науковці ІГН АН УРСР здобули досвід робіт в акваторії Світового океану, який у подальшому було реалізовано для подальшої розробки методик здійснення морських експедиційних робіт у морі, які не поступаються світовим аналогам.

\section{Бібліографічні посилання}

1. Бабинець А.. . Десять років морських геологічних досліджень / А. С. Бабинець, О. Ю. Митропольський // Вісник АН Української РСР. - 1972. - № 11.C. 72-75.

2. Бабинець А. Є. Морська гідрогеологія - нова галузь геологічних знань / А. Є. Бабинець, О. Ю. Митропольський [та ін.] // Вісник АН Української РСР. - 1982. № 12. - С. 79-83.

3. Батраков Г. Ф. Экспедиционные исследования на НИС «Михаил Ломоносов» / Батраков Г. Ф.; НАН Украины, Морской гидрофизический институт. - Севастополь, 2007. - С. 91-96.

4. Булгаков М. П. Експедиційні дослідження Світового океану НДС «Михаил Ломоносов»/ М. П. Булгаков, О. М. Суворов // Вісник АН Української PCP. - 1983. - № 5. - C. 70-75. 
5. Геворкян В. X. Морська геологія в ІГН НАН України (історія становлення, пошуки, проблеми, нові наукові напрями та школи) / В. Х. Геворкян, О. Ю. Митропольський // Геол. журн. -1996. - № 1-2. - С. 30-35.

6. Лебедсв Т. С. «Михайло Ломоносов» іде в Океан / Т. С. Лебедєв. - К.: Наук. думка, 1969. - 128 с.

7. Митропольський О. Ю. Науково-дослідний флот (минуле, сучасне, майбутнє) України / О.Ю.Митропольський, С. Г. Половка. - Київ - Умань: РВЦ «Софія», 2008. - $166 \mathrm{c.}$

8. Неиймин Г. Г. 20 лет в океане / Г. Г. Неиймин // Изв. АН СССР ФАО. 1978. - 14, № 6. - С. 680-682.

9. Папанин И. Д. Корабли науки. Океан и человек. Беседы по актуальным проблемам науки / И. Д. Папанин, Е. М. , Сузюмов. - М.: Знание, 1968. - С. 76-93.

10. Половка С. Г. Сто морських геологів України / С. Г. Половка. - Київ Умань: «Візаві», 2007. - 261 с.

11. Половка С.Г. Історія морських геологічних досліджень в Україні: автореф. дис. на здобуття наук. ступеня д-ра геолог. наук.: спец. 04.00.23 «історія геології» / Половка Сергій Григорович; Ін-т геологічних наук НАН України. - К., 2011. $-36 \mathrm{c}$.

12. Тумаров А. А. Морской гидрофизический институт. Корабли и люди. Страницы истории / А. А. Тумаров. - Севастополь, 2001. - 209 с.

Надійшла до редколегії 11.03.2014 p. 